\title{
Acerca de la prohibición de atribuir legitimación activa a la madre para deducir la acción de impugnación de la paternidad del esposo en el Derecho argentino: análisis de. su constitucionalidad
}

Víctor Bazán

\section{Planteo introductorio}

Utilizando un caso testigo que desnuda el criterio mayoritario de la Corte Suprema de Justicia de la Nación (en adelante: la Corte), nos proponemos indagar si el Art. 259 $9^{\circ}$ del Código Civil (en lo sucesivo: C.C.), particularmente cuando al mismo se le atribuye la negativa a adjudicar legitimación activa a la madre para impugnar la filiación matrimonial, guarda compatibilidad con la nueva normativa de la Constitución Nacional, introducida por la reforma de 1994, y, fundamentalmente, con la preceptiva emanada de los tratados internacionales sobre derechos humanos que ostentan jerarquía constitucional, esto es, que integran el bloque de constitucionalidad federal y valen tanto como la Carta Magna misma.

II. La solución dispensada por la Corte en la causa «D. de P. V., A. v. O., C. H.»

1. El caso

En la causa "D. de P. V., A. v. O., C. H.»', las instancias de mérito, fundándose en el Art. $259^{\circ}$ del C.C., resolvieron hacer lugar a la excepción de falta de legitimación activa de la madre para articular, por derecho propio, la acción de impugnación de paternidad matrimonial. 
Contra tal decisorio, la progenitora interpuso el recurso extraordinario federal, fundándose en que la limitación contenida en la precitada norma del C.C. -que no incluye a la madre del niño entre los legitimados activos para articular la acción de impugnación de paternidad matrimonial- violenta los arts. $1^{\circ} ; 17^{\circ}$, inc. $4^{\circ} ; 19^{\circ}$ y $24^{\circ}$ de la Convención Americana sobre Derechos Humanos (C.A.D.H.), $16^{\circ}$ de la Convención sobre la Eliminación de todas las Formas de Discriminación contra la Mujer (C.E.T.F.D.C.M.) y $2^{\circ} ; 7^{\circ} ; 8^{\circ}$, inc. $1^{\circ} ; 12^{\circ}$, inc. $1^{\circ}$ y $18^{\circ}$, inc. $1^{\circ}$ de la Convención sobre los Derechos del Niño (C.D.N.). Alega, además, que el fundamento que se atribuye a la prohibición de legitimación activa de la madre (y que radica en que lo contrario importaría reconocer su propio adulterio) no es invocable frente a la clara obligación de las autoridades de atender al interés superior del niño.

El Procurador General de la Corte, con sólidos fundamentos, dictaminó que correspondía hacer lugar al recurso extraordinario interpuesto y declarar la inconstitucionalidad del Art. $259^{\circ}$ del C.C. en tanto veda el ejercicio a la esposa de la acción de impugnación de la paternidad. En consecuencia, propiciaba la revocación de la sentencia de la anterior instancia que desconocía a la actora la legitimación para promover este tipo de procesos.

La Corte se expidió el 1 de noviembre de $1999^{2}$. La composición de los votos para dirimir el recurso intentado, en el seno del Alto Tribunal, fue la siguiente: la mayoría estuvo integrada por los ministros Nazareno, Moliné O’Connor, Fayt, Belluscio y Boggiano. Existió una

2 Cabe destacar que en idéntica fecha, la Corte resolvió la causa "O. 28. XXXII, Recurso de hecho, “O., S. A. c/ O., C. H." (vinculada con la sentencia que motiva la referencia y el comentario del texto: «D. de P. V., A. v. O., C.H.»), en la que mayoritariamente (Nazareno, Moliné O'Connor, Fayt, Belluscio, Petracchi y Boggiano) decidió hacer lugar a la queja del Asesor de Menores, declarar procedente el recurso extraordinario, revocar la sentencia impugnada (que había dejado sin efecto la designación de tutor especial efectuada por el magistrado de primera instancia y negado legitimación activa al Ministerio Pupilar para deducir la acción de impugnación de la paternidad sobre la base de la representación promiscua que le atribuía la ley) y disponer que el juez de primera instancia "deberá dar intervención al menor a fin de que ratifique la demanda establecida por el Ministerio Pupilar o la desista, sin perjuicio de la representación promiscua que deberá continuar ejerciendo dicho Ministerion. En voto conjunto, Bossert y Vázquez, se separaron de la solución mayoritaria, al propiciar (a diferencia de ésta) que la acción udeberá ser continuada por el menor $S$. con la asistencia del tutor designado y del Ministerio Pupilar conforme a la ley". 
disidencia conjunta de Petracchi y Bossert y un voto disidente individual de Vázquez.

\section{La percepción de la mayoría del Tribunal}

La mayoría triunfante, separándose del dictamen del Procurador General de la Corte, optó por confirmar la sentencia resistida. La trama argumental que la condujo a tal conclusión, puede ser sintetizada del siguiente modo:

a) Que «la consideración primordial del interés del niño, que la Convención sobre los Derechos del Niño -Art. 3.1-impone a toda autoridad nacional en los asuntos concernientes a los niños, orienta y condiciona toda decisión de los tribunales de todas las instancias llamados al juzgamiento de los casos, incluyendo obviamente a esta Corte [...], a la cual corresponde, como órgano supremo de uno de los poderes del Gobierno Federal, aplicar -en la medida de su jurisdicción- los tratados internacionales a los que el país está vinculado, con la preeminencia que la Constitución les otorga» (considerando $5^{\circ}$ ).

b) Que si bien los tratados internacionales sobre derechos humanos invocados por la recurrente no gozaban de jerarquía constitucional en octubre de 1985 (fecha de promulgación de la Ley $\mathrm{N}^{\circ} 23.264^{3}$, que introdujo notables reformas en materia de filiación y dio la redacción actual al Art. $259^{\circ}$ del C.C.), obligaban internacionalmente al Estado nacional y prevalecían sobre el derecho interno (considerando $6^{\circ}$ ); por tanto -razonan- a dicha fecha los legisladores conocían los límites impuestos por los tratados internacionales vigentes, empero de la discusión parlamentaria que precedió a la sanción de la aludida normativa no surge preocupación alguna sobre el ejercicio de algún derecho propio de la mujer, sino sólo la conveniencia o inconveniencia de su eventual actuación en representación del hijo durante su minoridad, con lo que -colige el voto mayoritario- «la reforma legislativa tuvo como consideración primordial el valor que apreció como el más beneficioso para el hijo, esto es, el conocimiento de su identidad biológi- 
ca permitiéndole el desplazamiento en todo tiempo de una filiación no acorde con el lazo biológico, superando incluso los límites éticos (conf. antecedentes parlamentarios de la Ley $\mathrm{N}^{\circ} 23.264$, Cámara Diputados Nac. 1985, reunión 46, p. 7578)" [considerando $7^{\circ}$ ];

c) En cuanto al inc. d', párrafo 1, del Art. $16^{\circ}$ de la C.E.T.F.D.C.M. (invocado por la actora), la acción que la ley argentina atribuye al marido y no a la esposa y madre del niño, está evidentemente relacionada con el derecho del hijo a conocer su verdadera identidad, derecho este último que -aun cuando no absoluto- goza de jerarquía constitucional (considerando 12); además, puso énfasis (con cita doctrinaria y de la OC-4/84 de la Corte Interamericana de Derechos Humanos) en afirmar que el principio de igualdad de todas las personas ante la ley es «el derecho a que no se establezcan excepciones o privilegios que excluyan a unos de lo que se concede a otros en iguales circunstancias" y que no todo tratamiento jurídico diferente es propiamente discriminatorio ya que no toda distinción de trato puede considerarse ofensiva de la dignidad humana (considerando 13).

d) A las precedentes consideraciones anuda que el Estado goza de un razonable margen de apreciación de las distinciones que, dentro de los parámetros señalados, puede legítimamente formular por imperativos de bien común, lo que conduce a la mayoría a aseverar que «la paternidad y la maternidad no son absolutamente iguales y por ello, el legislador puede contemplar razonables diferencias» (considerando 14), extrayendo que el Art. $259^{\circ}$ del C.C. no se funda en un "privilegio masculino" sino que suministra al marido la vía legal para destruir una presunción legal -que, obviamente, no pesa sobre la mujer ya que su maternidad queda establecida por la prueba del nacimiento y la identidad del nacido [Art. $242^{\circ}$ ibid.]- para que pueda desligarse de las obligaciones de una paternidad que le es ajena (id. considerando).

e) Entiende que la presunción de paternidad legítima no tiene su fundamento en la presunción de inocencia de la cual goza la mujer por su carácter de casada con relación al adulterio, «sino en el valor institucional de la familia legítima y en la conveniencia de dar emplazamiento inmediato al niño nacido durante el matrimonio» (considerando 15). Afirma, además, que de la tensión entre el imperativo de asegurar el acceso al conocimiento del vínculo biológico y el de mantener el sosiego y la certeza en los vínculos familiares (de acuerdo con la ponderación realizada por el Poder Legislativo de la Nación) surge 
la ampliación al hijo de la legitimación activa en la acción de impugnación de la paternidad, que quedara consagrada por la reforma de la Ley $\mathrm{N}^{\circ} 23.264$ (id. considerando).

f) Añade que una distinta composición de los valores en tensión podrá ser eventualmente consagrada por el Poder Legislativo de la Nación, pero -de lege lata- cabe concluir que el Art. $259^{\circ}$ del C.C. «satisface el juicio de compatibilidad constitucional puesto que no transgrede los derechos fundamentales invocados por la recurrente, sino que plasma una reglamentación posible de los valores en tensión, en concordancia con los derechos y garantías de jerarquía constitucional» (considerando 17).

g) Finaliza afirmando que uen el derecho vigente actualmente en la República, la negación de legitimación activa de la madre en la acción de desconocimiento de la paternidad no produce efectos definitivos sobre la filiación impugnada, ya que dicha acción queda abierta al principal interesado, que es precisamente el hijo» (considerando 18).

\section{La disidencia de Petracchi y Bossert}

Distanciándose del criterio mayoritario, Petracchi y Bossert propiciaban, de conformidad con lo dictaminado por el defensor oficial y el Procurador General ${ }^{4}$, declarar procedente el recurso extraordinario, revocar la sentencia apelada y rechazar la excepción de falta de legitimación interpuesta por el demandado. En sustento de su voto sostuvieron:

a) Que la consideración primordial del interés del niño (Art. 3.1 de la C.D.N.) impone a toda autoridad nacional en los asuntos concernientes a ellos, orienta y condiciona toda decisión de los tribunales de todas las instancias llamados al juzgamiento de los casos, incluyendo obviamente a la Corte (Fallos, 318:1269, especialmente considerando 10) [considerando $5^{\circ}$.

4 Si bien Petracchi y Bossert (y, a su tiempo, también Vázquez) dijeron que la solución que propiciaban coincidía con lo dictaminado por el Procurador General, cabe apreciar que -a diferencia del dictamen de éste- el voto de aquellos magistrados no incluía -al menos expresamente- la declaración de inconstitucionalidad del Art. $259^{\circ}$ del C.C. por vedar el ejercicio a la esposa de la acción de impugnación de la paternidad (ver en Fallos, 322:27 19, la parte in fine del dictamen del Procurador General de la Corte). 
b) En el considerando $7^{\circ}$ expresan que el Art. $16^{\circ}$, inc. 'd', de la C.E.T.F.D.C.M. establece específicamente que los Estados partes asegurarán, en condiciones de igualdad entre hombres y mujeres, los mismos derechos y responsabilidades como progenitores, cualquiera que sea su estado civil, en materias relacionadas con sus hijos, norma que es inmediatamente operativa ante una situación de la realidad como la planteada en autos, sin necesidad de instituciones que deba establecer el Congreso (Fallos, 315:1492, considerando 20). Adunan que al encontrarse aquella Convención entre los tratados humanitarios modernos, sus cláusulas gozan de la presunción de operatividad y los derechos que establecen pueden ser invocados, ejercidos y amparados sin el complemento de disposición legislativa alguna, lo que se funda en el deber de respetar los derechos del hombre, axioma central del derecho internacional de los derechos humanos (fallos, 315:1492, disidencia de los jueces Petracchi y Moliné O’Connor, considerando 15).

Indican que, aun cuando el Art. $259^{\circ}$ del C.C. no niega expresamente la legitimación de la mujer, la Corte ha señalado que la violación de un tratado internacional puede acaecer tanto por el establecimiento de normas internas que prescriban una conducta manifiestamente contraria, cuanto por la omisión de establecer disposiciones que hagan posible su cumplimiento; situaciones, ambas, que resultarían contradictorias con la previa ratificación internacional del tratado, por lo que significarían el incumplimiento o la repulsa de éste, con las consecuencias perjudiciales que de ello pudieran derivarse (Fallos, 315:1492, considerando 16).

Puntualizan que entre las medidas necesarias en el orden jurídico interno para cumplir el fin de la Convención deben considerarse comprendidas las sentencias judiciales, por lo que puede el Tribunal determinar las características con que ese derecho, ya concedido por aquélla, se ejercitará en el caso concreto (fallos, 315:1492, considerando 22).

c) Ponen de manifiesto que la determinación de la filiación constituye para la madre una de las "materias relacionadas con sus hijos" a las que alude la Convención, siendo evidente que ella y su marido -de acuerdo con la limitada legitimación acordada por el Art. $259^{\circ}$ del C.C.- no encuentran asegurados sus derechos en condiciones de igualdad, dado que la madre no puede impugnar la presunción de paternidad que la ley asigna a su marido, mientras que éste puede hacerlo tanto respecto de su paternidad como de la maternidad de su mujer (considerando $8^{\circ}$ ) 
d) En el considerando $9^{\circ}$ acotan que constituye doctrina de la Corte considerar que son válidas las distinciones normativas para supuestos que se estimen diferentes, siempre que la discriminación no sea arbitraria ni importe una ilegítima persecución o indebido privilegio de personas o grupos de personas, con la consecuencia de que se excluya a unos de lo que se concede a otros en iguales circunstancias; doctrina a la luz de la cual -siempre según el voto de Petracchi y Bossert- el no reconocimiento de la acción de impugnación a la madre -en las condiciones de autos- resulta arbitraria por carencia de fundamento válido $y$, por tanto, discriminatoria.

Señalan que el interés que justifica la acción de la madre para destruir el vínculo con quien -considera- no es el verdadero padre y poder así establecer el vínculo con el padre biológico, se funda en la trascendental incidencia que ello tendrá en el contenido existencial de su vínculo con su hijo y en los múltiples y variados aspectos de la vida de éste en los que se interrelacionan la voluntad y los actos de ambos progenitores, además de que pretender escindir los dos vínculos de filiación (el de cada progenitor y el hijo), como si se tratara de entidades ajenas y desprovistas de interdependencia, para así negar interés legitimante a la madre actora, significa desconocer el aspecto básico, el más elemental, de la vida de familia.

Concluyen afirmando que la ponderación realizada por el legislador en el Art. $259^{\circ}$ del C.C. sobre lo que resulta conveniente para mantener el sosiego y la certeza en los vínculos familiares, negando acción a la madre, representa una actitud discriminatoria contra quien tiene un interés jurídico para accionar, en el sentido de acomodamiento a las normas constitucionales de jerarquía superior.

e) Acotan que la identidad y la conveniencia del menor, protegidas por normas de las convenciones con jerarquía constitucional, sólo hallan plena tutela a través del reconocimiento de la acción a la madre, ya que puede ser ejercida aun antes de que el niño cuente con discernimiento para actos lícitos (Art. $921^{\circ}$ del C.C.) y el desarrollo de su personalidad, el uso del nombre que realmente le corresponde, su vida familiar, afectiva y social, obtienen incuestionable beneficio si la desvinculación con quien no es su padre biológico sucede en la infancia, posibilitándose -como pretende la actora en autos- el establecimiento del vínculo con el verdadero padre (considerando 10). 
f) Exponen, además, que negar acción a la madre implica sostener una ficción, desde que la acción del hijo normalmente sólo podrá fundarse en el conocimiento de los hechos que la madre posee, dependiendo -entonces- la acción de la decisión de la madre que proporciona los elementos para actuar (considerando 11).

g) Previo a citar algunos casos en el derecho comparado de países de cultura jurídica afín que reconocen a la madre la acción de impugnación discutida en la causa (considerando 13$)^{5}$, destacan que no es argumento válido para justificar la discriminación en que incurre el Art. $259^{\circ}$ del C.C., sostener que resulta inadmisible la invocación por la mujer de su propia torpeza, quien al impugnar la paternidad del marido reconoce haber cometido adulterio, ya que -más allá de que el hijo pudo haber sido concebido antes del matrimonio- debe tenerse presente que el adulterio -como cualquier otra injuria- puede tener consecuencias en las relaciones personales de los cónyuges mas no enervar el derecho de la mujer a la no discriminación y el derecho a la protección de la identidad del menor contemplado en el Art. $8^{\circ}$ de la C.D.N. (considerando 12).

\section{El voto disidente de Vázquez}

Por último, Vázquez coincidió con la decisión final que postulaban Petracchi y Bossert, mas recorrió una línea argumental un tanto diversa de la discurrida por éstos. Veamos:

a) En efecto, comenzó afirmando que el principio sentado en el Art. $3^{\circ}$ de la C.D.N. (consideración primordial al interés superior del niño) condiciona las decisiones de los tribunales de todas las instancias llamados al juzgamiento de los casos, incluyendo obviamente a la Corte (Fallos, 318:1269) -considerando $5^{\circ}$-, por lo que -a su criteriocorrespondía analizar si la omisión del Art. $259^{\circ}$ del C.C. acerca de la posibilidad de la madre de impugnar la paternidad de su marido, va en desmedro del interés superior del hijo, examen para el que debe recurrirse

5 Concretamente, la referencia apunta al Art. $235^{\circ}$ del Código Civil italiano; al Art. $136^{\circ}$ del Código Civil español; y al Art. $318^{\circ}$ del Código Civil francés, aunque con la salvedad de que éste sólo admite que la acción se promueva tras la muerte del marido o el divorcio y exige que se acumule la acción de legitimación de la madre y su nuevo marido, evitando así el disfavor en que se encuentra, en el derecho francés, el hijo adulterino en materia sucesoria. 
al marco ético y de valores de la C.D.N. (Fallos, 322:1349, voto de Vázquez) -considerando $6^{\circ}-$.

De tal compulsa, Vázquez concluye que el Art. $259^{\circ}$ del C.C. contradice los arts. $8^{\circ}$, parágrafo $1^{\circ}$, y $7^{\circ}$, parágrafo único, de la C.D.N.; además, descarta el argumento doctrinario que sostiene que la omisión normativa se justifica porque se trata de uno de esos casos en que el derecho a la identidad reconoce sus límites en pos de que no se lesione la unidad familiar, al afirmar que el sentido común indica que si la madre decide actuar es porque existe una ruptura en la comunidad de vida y un interés aun mayor que la impulsa a echar por tierra una ficción al intentar dar a su hijo su verdadero emplazamiento filial. También rechaza la explicación según la cual no se le acuerda legitimación activa a la mujer porque ello traería aparejado el reconocimiento de su infidelidad y nadie puede beneficiarse de una acción alegando su propia torpeza, ya que -en la visión del juez disidente- el actuar de la madre apunta al hijo, no a la obtención de un rédito personal (considerando $7^{\circ}$ ).

b) Ya desde otro perfil, señala que el Art. $16^{\circ}$, inc. 'd', de la C.E.T.F.D.C.M. es operativo cuando puede actuar inmediatamente ante situaciones de la realidad -como la planteada en autos-, sin necesidad de instituciones que deba establecer el Congreso (fallos, 320:2948; 321:885, voto de Vázquez; 321:2314, disidencia de Vázquez, y sus citas con remisión a 315:1492, entre otros). Añade que si bien el Art. $259^{\circ}$ del C.C. no niega expresamente la legitimación de la mujer, la Corte ha dicho que la violación de un tratado internacional puede acaecer tanto por el establecimiento de normas internas que prescriban una conducta manifiestamente contraria, cuanto por la omisión de establecer disposiciones que hagan posible su cumplimiento (fallos, 315:1492) -considerando $8^{\circ}-$.

c) Pone énfasis en aseverar que el Art. $259^{\circ}$ del C.C. que sólo da al marido la posibilidad de buscar la verdad y la obstaculiza a la madre, afecta la garantía de igualdad dado que la filiación es una materia que obviamente atañe a los hijos, por lo que -de acuerdo con la C.E.T.F.D.C.M.- ambos progenitores deben tener $y$ tienen iguales responsabilidades respecto de ellos y un trato diferenciado deparado a los padres pone de resalto la falta de reconocimiento de la norma acerca de que ellos ocupan el mismo lugar e idéntica posición en el ámbito familiar (considerando $9^{\circ}$ ). 
d) Por último, sostiene que en el sub lite la acción de la madre tuvo lugar con posterioridad al surgimiento de una crisis matrimonial que afectó profundamente la vida familiar y que de las condiciones en que aquélla planteó la impugnación se aprecia que el objetivo perseguido no es otro que clarificar definitivamente la verdadera identidad de su hijo a través de la concordancia entre el vínculo biológico y el jurídico (considerando 10).

\section{Algunas reflexiones que el fallo nos sugiere}

Liminarmente, anunciamos nuestra visión discrepante con la posición reduccionista inoculada al fallo por la mayoría sentenciante. Sin ánimo de agotar la cuestión, pasaremos a reseñar algunas consideraciones e interrogantes que nos sugieren ciertos fundamentos brindados en sustento de la postura triunfante.

1. El argumento relativo al conocimiento por parte de los parlamentarios creadores de la Ley $\mathrm{N}^{\circ} 23.264$ acerca de las imposiciones y límites de los tratados internacionales vigentes

El argumento de la mayoría relativo a que si bien los tratados internacionales sobre derechos humanos invocados por la recurrente no gozaban de jerarquía constitucional en octubre de 1985 (fecha de promulgación de la Ley $\mathrm{N}^{\circ} 23.264$ ), los legisladores conocían los límites impuestos por los tratados internacionales vigentes, y que de la discusión parlamentaria que precedió a la sanción de la aludida normativa no surge preocupación alguna sobre el ejercicio de algún derecho propio de la mujer, sino sólo la conveniencia o inconveniencia de su eventual actuación en representación del hijo durante su minoridad, resulta más aparente que real, pues aun cuando por una cuestión cronológica a la época de la discusión parlamentaria que derivó en la Ley N²3.264 los congresistas conocieran la existencia de los tratados internacionales y los límites impuestos por éstos al Estado argentino, cabe recordar que la ratificación en sede internacional de diversos instrumentos internacionales sobre derechos humanos obedeció a una circunstancia históricoinstitucional de gran trascendencia: el readvenimiento de la democracia operado en 1983 y la necesidad de reaccionar -al menos desde la literalidad 
convencional- contra tantos años de opresión y múltiples y flagrantes violaciones a los derechos humanos.

Sin embargo, tanto en la percepción parlamentaria cuanto en la visión jurisprudencial de la Corte hubo de transcurrir un prolongado lapso de tiempo para que se comenzara a consolidar la conciencia jurídica en el sentido de la prevalencia de los tratados internacionales sobre el derecho interno, las imposiciones del Art. $27^{\circ}$ de la Convención de Viena de 1969 sobre el Derecho de los Tratados-precepto respecto del que volveremos-, y la potencial responsabilidad internacional del Estado argentino por el incumplimiento de las obligaciones asumidas internacionalmente.

Para graficar lo expuesto, valga recordar que el muy famoso caso «Ekmekdjian c/ Sofovich" ${ }^{6}$, que entrañó un punto de inflexión en la materia y significó un giro de 180 grados en el timón jurisprudencial del máximo tribunal nacional, fue dictado el 7 de julio de 1992, es decir, más de seis años después de la discusión parlamentaria que diera origen a la Ley $\mathrm{N}^{\circ} 23.264$.

\section{De ficciones y discriminaciones}

Si el valor primordialmente buscado por la reforma legislativa que plasmara en la redacción actual del Art. $259^{\circ}$ del C.C. (Ley N 23.264 mediante) fue el más beneficioso para el hijo trasuntable en el conocimiento de su identidad biológica, inquirimos si la solución de la Corte se compadece cabalmente con tan trascendente valor, pues -contrariamente- al negar legitimación a la madre para articular la acción de impugnación de la paternidad del marido, y a través de una ficción, termina cerrando los ojos a la real posibilidad de garantizar la búsqueda de la identidad biológica del menor. Como alegan Petracchi y Bossert en su disidencia, negar legitimación a la madre significa sostener una ficción puesto que la acción del hijo normalmente sólo podrá fundarse en el conocimiento de los hechos que la madre posee, dependiendo aquélla -entonces- de la decisión de la progenitora que proporciona los elementos para actuar (considerando 11).

En tal sentido, nos preguntamos: jes lógico privilegiar una ficción legal frente a la posibilidad de lograr el real emplazamiento familiar del

6 Fallos, 315:1492, reiteradamente citado en las disidencias. 
menor e intentar que coincida su vínculo biológico con el jurídico? Al obturar dogmáticamente la legitimación de la madre, ¿̨se habrá privilegiado el interés superior del menor? ¿Cabrá sostener que el argumento de la negativa a acordar legitimación activa a la madre, que enraíza en la imposibilidad de reconocer la presunta infidelidad y la consecuente improcedencia de beneficiarse de una acción alegando su propia torpeza, resulte axiológicamente más relevante que el derecho a la identidad del menor, la necesidad de preservar su realidad biológica y la obligación de no discriminar a la progenitora?

Desde nuestra óptica, constituye una verdad inocultable que la filiación es materia que atañe al hijo y que vincula tanto al padre cuanto a la madre. Entonces, ¿es sustentable la proscripción de acordar legitimación a la madre para impugnar la filiación, misma que -por una ficción legal- se atribuye al marido? ¿No hay allí espacio (y excusa) para alojar una discriminación en detrimento de la progenitora y quebrar la garantía de igualdad con su (ex) cónyuge 7 ? Sobre todo si, como lo sostiene el Procurador General en el ap. III de su dictamen, convergían -desde el plano fáctico- circunstancias concretas omitidas por el a quo, invocadas por la actora y que habrían quedado ratificadas por las constancias del expediente. Se refería a que la accionante había contraído enlace con quien según indican las pruebas biogenéticas sería el padre biológico de su hijo, unión de la que además nacieron otros menores, hermanos del primero; asimismo, aludía a que el primer esposo de la demandante habría sufrido imposibilidades físicas que le impedían procrear.

Tampoco nos parece suficiente la fundamentación del considerando 18 del voto mayoritario, cuando afirma que «en el derecho vigente actualmente en la República, la negación de legitimación activa de la madre en la acción de desconocimiento de la paternidad no produce efectos definitivos sobre la filiación impugnada, ya que dicha acción queda abierta al principal interesado, que es precisamente el hijon -énfasis añadido-, pues como acertadamente quedó plasmado en la moción disidente de Petracchi y Bossert (considerando 10), la identidad y la conveniencia del menor sólo hallan plena tutela con el reconocimiento de la acción a la madre, ya que ella puede ser ejercida inclusive antes de que el niño cuente con discernimiento para los actos lícitos (Art. $921^{\circ} \mathrm{del}$ C.C.), permitiéndose así la efectiva protección en todo tiempo de su identidad, lo que atiende, además, a su conveniencia, desde que el 
desarrollo de su personalidad, el uso del nombre que realmente le corresponde, su vida familiar, afectiva y social, obtienen incuestionable beneficio si sucede en la infancia la desvinculación con quien no es el padre biológico, posibilitándose así el establecimiento del vínculo con el verdadero padre, como lo pretende la actora en autos.

\section{3. ¿Interés superior del menor?}

Nótese que cualquiera fuera el camino que se discurra (examinando con detenimiento los postulados de la C.E.T.F.D.C.M. -al modo como lo efectúan Petracchi y Bossert- o haciéndolo en los de la C.D.N. -como lo concreta Vázquez-) el punto de confluencia al que se arriba, y que traduce el valor más trascendente que subyace en la intersección de la normativa pertinente de la primera de las Convenciones nombradas (v.gr., el Art. $16^{\circ}$, inc. $1^{\circ}$, ap. 'd') y la de la C.D.N. (por ejemplo, los arts. $2^{\circ}$, inc. $1^{\circ} ; 3^{\circ}$, inc. $1^{\circ} ; 4^{\circ} ; 7^{\circ}$, inc. $1^{\circ} ; 8^{\circ} ; 12^{\circ}$ ), estriba en la obligación estatal de considerar primordialmente el interés superior del menor.

En efecto, el Art. $16^{\circ}$, inc. $1^{\circ}$, de la C.E.T.F.D.C.M. establece que los Estados partes adoptarán todas las medidas adecuadas para eliminar la discriminación contra la mujer en todos los asuntos relacionados con el matrimonio y las relaciones familiares y, en particular, asegurarán, en condiciones de igualdad entre hombres y mujeres, los mismos derechos y responsabilidades como progenitores, cualquiera que sea su estado civil, en materias relacionadas con los hijos; determinando que en todos los casos, los intereses de los hijos serán la consideración primordial -énfasis propio- (el último tramo referenciado corresponde al ap. 'd' del inc. $1^{\circ}$ de la norma en cuestión).

Por su parte, y sin ánimo de lograr taxatividad, del articulado de la C.D.N. puede observarse que (en todos los casos el subrayado ha sido agregado):

- El Art. $2^{\circ}$, inc. $1^{\circ}$, dispone que los Estados Parte respetarán los derechos enunciados en dicha Convención y asegurarán su aplicación a cada niño sujeto a su jurisdicción, sin distinción alguna;

- El Art. $3^{\circ}$, inc. $1^{\circ}$, establece que en todas las medidas concernientes a los niños que tomen las instituciones públicas o privadas de bienestar social, los tribunales, las autoridades administrativas o los órganos legislativos, una consideración primordial a que se atenderá será el interés superior del niño; 
- $\quad$ El Art. $4^{\circ}$ preceptúa que los Estados partes adoptarán todas las medidas administrativas, legislativas $y$ de otra indole para dar efectividad a los derechos reconocidos en la Convención;

- El Art. $7^{\circ}$, inc. $1^{\circ}$, reza que el niño será inscrito inmediatamente después de su nacimiento y tendrá derecho, desde que nace, a un nombre, a adquirir una nacionalidad y, en la medida de lo posible, a conocer a sus padres;

- El Art. $8^{\circ}$ reconoce el derecho a preservar la identidad del niño;

- El Art. 12 pone en funcionamiento el derecho del niño a ser escuchado en todo procedimiento judicial o administrativo que lo afecte, ya sea directamente o por medio de un representante o de un órgano apropiado (Art. $12^{\circ}$, inc. $2^{\circ}$ ); y

- Por último, el Art. $41^{\circ}$ señala que nada de lo dispuesto en la Convención afectará a las disposiciones que sean más conducentes a la realización de los derechos del niño y que puedan estar recogidas en: a) el derecho de un Estado parte; o b) el derecho internacional vigente con respecto a dicho Estado.

Luego de tal reseña normativa, se impone el interrogante acerca de si la solución insuflada a la causa por la mayoría de la Corte tuvo en consideración el verdadero interés superior del menor, al abroquelarse detrás de una visión reduccionista en materia de legitimación procesal que, en definitiva, se erige en una rémora para el pleno despliegue del derecho constitucional a la identidad y a obtener judicialmente la coincidencia de la filiación legal con la biológica ${ }^{8}$-en la medida en que ello resulte más beneficioso para el menor--

7 Más allá de los presupuestos antidiscriminatorios establecidos en la C.E.T.F.D.C.M. (arts. $2^{\circ} ; 3^{\circ} ; 4^{\circ}$, inc. $1^{\circ} ; 16^{\circ}$, inc. $1^{\circ}$, ap. 'd'), existen otros prefigurados en otros instrumentos internacionales sobre derechos humanos con jerarquía constitucional, v.gr., en la C.A.D.H. (arts. $1^{\circ} ; 17^{\circ}$, inc. $4^{\circ} ;$ y $2^{\circ}$ ), la Declaración Americana de los Derechos y Deberes del Hombre (Art. $2^{\circ}$ ), la Declaración Universal de Derechos Humanos (arts. $1^{\circ}, 2^{\circ}, 7^{\circ}$, $\left.10^{\circ}, 16^{\circ}\right)$.

Ello, por supuesto, sin olvidar la existencia de una normativa genérica antidiscriminatoria. Aludimos a la Ley $\mathrm{N}^{\circ} 23.592$, del año 1988, que sanciona civil y penalmente los actos y omisiones de tal carácter, reputándose tales aquellos basados en motivos de raza, religión, nacionalidad, ideología, opinión política o gremial, sexo, posición económica, condición social o caracteres físicos.

8 Explica Zannoni que la adecuación del emplazamiento familiar de la persona a su presupuesto biológico traduce la tradicional aspiración a la concordancia entre el vínculo 
La posición mayoritaria del Tribunal conduce a una situación disvaliosa que, casualmente, contradice su ampulosa declaración contenida en el considerando $5^{\circ}$, en el que puede leerse que «la consideración primordial del interés del niño, que la Convención sobre los Derechos del Niño -Art. 3.1-impone a toda autoridad nacional en los asuntos concernientes a los niños, orienta y condiciona toda decisión de los tribunales de todas las instancias llamados al juzgamiento de los casos, incluyendo obviamente a esta Corte...». Al respecto, y con acertado realismo, Bidart Campos al comentar el fallo enfatiza que «se carga la mirada en el núcleo familiar, en la esposa, en el marido, en la política legislativa, pero se cae en la peor de las miopías: la que no visualiza que la pauta orientativa -de aplicación imperativa- era el interés superior del niño"?

\section{En torno del adulterio y la imposibilidad de alegar la propia torpeza}

Por su parte, cabe inquirir si la legitimación activa del hijo para impugnar la paternidad matrimonial (reconocida en el Art. $259^{\circ} \mathrm{del}$ C.C.) no confluye en la invocación del adulterio de la madre (argumento que, precisamente, constituye uno de los que se esgrimen para negar la legitimación de ésta) ${ }^{10}$. Al respecto, recuerda Méndez Costa

biológico y el vínculo jurídico que determina tal emplazamiento. Añade que el criterio de verdad biológica subyace en lo que se ha dado en llamar el derecho a la identidad personal y que la identidad filiatoria es susceptible de ser captada en dos dimensiones: su faz estática (en la que aquella identidad está constituida por el dato biológico: la procreación del hijo), y su faz existencial o dinámica (en la que dicha identidad presupone el arraigo de vínculos paterno-filiales asumidos y recíprocamente aceptados por padres e hijos en el contexto de las relaciones familiares). De ello extrae que el concepto de identidad filiatoria como pura referencia a su presupuesto biológico no es suficiente para definir, por sí mismo, la proyección dinámica de la identidad filiatoria, por lo que el concepto de identidad filiatoria de alguien no es necesariamente correlato del dato puramente biológico determinado por la procreación (Zannoni, Eduardo A.: «Adopción plena y derecho a la identidad personal. La verdad biológica: ¿`Nuevo paradigma en el derecho de familia?», La Ley, 29/05/98, Buenos Aires [en adelante: Bs. As.], República Argentina [en lo sucesivo: Rep. Arg.], p. 1).

9 Germán J. Bidart Campos: «La legitimación de la madre para impugnar la paternidad del marido: ¿Y los derechos del niño?n, La Ley, T² 2000-B, Bs. As., Rep. Arg., p. 23.

10 Ya antes de la sanción de la Ley $N^{\circ} 23.264$, Grosman sostenía que siempre una acción de reclamación de estado de un hijo adulterino significa atribuir adulterio al padre 
que la legitimación activa del hijo contra su filiación paterna matrimonial constituyó un tema conflictivo durante la vigencia del Código Civil en su redacción originaria, época en la que se hicieron oír muchas voces autorizadas a favor y en contra; añade la autora citada que el argumento decisivo para negar entidad jurídica a esa legitimación era de orden ético porque equivalía a autorizar la invocación del adulterio de la madre ${ }^{11}$.

Además, y como con acierto afirmaban Petracchi y Bossert en su disidencia, negar acción a la madre implica sostener una ficción puesto que la acción del hijo normalmente sólo podrá fundarse en el conocimiento de los hechos que la madre posee y, por tanto, la acción dependerá de la decisión de aquélla en el sentido de aportar los elementos para actuar. Por su parte, el citado adulterio -al igual que cualquier otra causal habilitante del divorcio vincular o la separación personal- puede tener consecuencias en las relaciones personales de los cónyuges (en función de la violación del deber de fidelidad de la esposa) mas no es idóneo para enervar el derecho de la mujer a la no discriminación, lo que por su parte- se vincula con la igualdad jurídica de los esposos- (Art. $16^{\circ}$, inc. $1^{\circ}$, ap. ' $d$ ', de la C.E.T.F.D.C.M.) y el derecho a la protección de la identidad del menor contemplado en el Art. $8^{\circ}$ de la C.D.N.

Lubertino Beltrán ha sostenido que hay supuestos en los que la "torpeza" no existe, si se entiende "adulterio" por "torpeza», por ejemplo, en el caso del hijo nacido dentro de los 180 primeros días desde la celebración del matrimonio; y si por "torpeza" se entiende "unión sexual no matrimonial», existen casos donde la "torpeza" que se alega es el presupuesto fáctico del emplazamiento en el nuevo estado de familia, v.gr. el reconocimiento del hijo extramatrimonial ${ }^{12}$.

o a la madre, añadiendo que si el hijo no pudiera invocar tal adulterio, la Ley $\mathrm{N}^{\circ} 14.367$ perdería vigencia, resultado al cual es absurdo arribar y a esta consecuencia se llega cuando se arguye que no es posible al hijo invocar la torpeza de la madre. Finaliza destacando que, con igual criterio, se podría sostener que no puede invocarse la del padre, pues tiene idéntico contenido ético-jurídico, llegándose así a la desnaturalización de la Ley $\mathrm{N}^{\circ} 14.367$ (Cecilia P. Grosman: Acción de impugnación de la paternidad del marido, Ed. Ábaco, Bs. As., Rep. Arg., 1982, p. 232).

11 María Josefa Méndez Costa en: Méndez Costa, María Josefa y D’Antonio, Daniel Hugo: Derecho de Familia, T III, Rubinzal-Culzoni, Santa Fe, Rep. Arg., 1996, p. 136.

12 María José Lubertino Beltrán: «Algunas reflexiones sobre la nueva Ley $N^{\circ} 23.264$ », La Ley, 1986-B, Bs. As., Rep. Arg., p. 1061. En opinión de la autora citada, allí se emplaza la contradicción, ya que el hombre adúltero puede reconocer a sus hijos extramatrimoniales 
A todo evento, y como un elemento insoslayable a tomar en consideración para evitar la parcialización de un enfoque actual de la cuestión, cabe recordar que el delito penal de adulterio ha sido abrogado por la Ley $\mathrm{N}^{\circ} 24.453^{13}$, cuyo Art. $3^{\circ}$ deroga el Capítulo I y la rúbrica "Adulterio" del Título III, Libro Segundo, del Código Penal de la Nación, y su Art. $4^{\circ}$ hace lo propio con el Art. $118^{\circ}$ del mencionado plexo normativo penal.

Por su parte, y ante la tensión que plantea el voto mayoritario de la Corte entre la «imposibilidad de alegar la propia torpeza (adulterio)» por parte de la madre y el «respeto por los derechos y garantías constitucionales» (emergentes del texto y del espíritu de la Carta Magna o de la preceptiva de los tratados internacionales con valencia constitucional), creemos que la respuesta es obvia y el primero de los extremos debe necesariamente ceder frente a la mayor jerarquía -normativa $y$ axiológica- de la imposición constitucional. Ello, claro está, siempre que consintiéramos el desplazamiento del núcleo real de la cuestión que, por esa vía, concreta la mayoría del Alto Tribunal.

Por ende, desde una u otra óptica, el argumento de la invocación de adulterio no es decisivo y carece de suficiente entidad para sustentar la posición negatoria de la legitimación de la madre.

\section{En punto al «margen de apreciación estatal»}

Desde otro perfil, no compartimos el argumento mayoritario relativo a que la exclusión de la mujer no es discriminatoria porque dentro del «margen de apreciación" del Estado nacional se trataría de una de las distinciones que está habilitado a formular legitimamente por imperativos de bien común (considerando 14).

$\mathrm{Al}$ respecto, en primer lugar y aun cuando se admitiera la existencia y la viabilidad del «margen de apreciación» estatal, éste no podría ser ilimitado (uno de los límites estaría dado por la pauta pro homine-sobre la que volveremos-), ni podría derogar -como señala Valiña- algunos principios generales que confrontan la doctrina del margen de apreciación con los derechos individuales consagrados y las obligaciones internacionales voluntariamente asumidas por los Estados a través de la ra- 
tificación de los diversos tratados de protección de los derechos humanos ${ }^{14}$.

Por otra parte, cabe destacar que la expresión uimperativos de bien común» resulta conceptualmente vaga y difusa, por lo que una interpretación exacerbada de la misma podría conducir a que cualquier conducta restrictiva de los derechos reconocidos en los tratados internacionales sobre derechos humanos con valencia constitucional o, como hipótesis de mínima, supralegal, quedara hermenéuticamente justificada al influjo de un determinado «imperativo de bien común", con la consecuente oclusión del derecho de que se trate.

Por ello, en el particular no sería impertinente cuestionar la alegación de la Corte (cuando pretende desechar la descalificación de la que es objeto el Art. $259^{\circ}$ del C.C. a causa de la discriminación en contra de la madre en que incurre) apoyándose en la doctrina de la «autonomía de conceptos» reseñada por Valiña, en cuya virtud se rechaza la posibilidad de una definición totalmente propia de cada Estado independientemente de la naturaleza del concepto según el propio tratado $^{\text {15 }}$; en el caso, los claros postulados de la C.E.T.F.D.C.M. y de la C.D.N.

\section{La importancia del principio pro homine}

Por último, y en caso de duda para dilucidar si corresponde acordar legitimación a la madre y superar la rémora discriminatoria que germina en el Art. $259^{\circ}$ del C.C., no cabría soslayar las irradiaciones emergentes del mencionado principio pro homine o favor libertatis ${ }^{16}$, consagra-

13 B.O. del $07 / 03 / 95$.

14 Liliana Valiña: «El margen de apreciación de los Estados en la aplicación del derecho internacional de los derechos humanos en el ámbito interno", en Martín Abregú y Christian Courtis (compiladores): La aplicación de los tratados sobre derechos humanos por los tribunales locales, CELS, Editores del Puerto, Bs. As., Rep. Arg., 1997, p. 175.

15 Ibidem, p. 185.

16 Tal pauta ha sido inoculada al texto y al espíritu de la Constitución por conducto de la reforma de 1994. Sobre el particular, pueden verse los siguientes trabajos de Víctor Bazán: «El hábeas data y el ejercicio del derecho de autodeterminación informativa dirigido a acceder a archivos, registros o bancos de datos estatales de seguridad y a requerir información sobre personas desaparecidas», Revista Argentina de Derechos Humanos, Año 1, $\mathrm{N}^{\circ}$ 0, CELS - Universidad de Lanús, Ed. Ad Hoc, Buenos Aires, 
do por ejemplo en el Art. $5^{\circ}$ del Pacto Internacional de Derechos Económicos, Sociales y Culturales, el Art. $5^{\circ}$ del Pacto Internacional de Derechos Civiles y Políticos, el Art. $29^{\circ}$ de la C.A.D.H., el Art. $1^{\circ}$ (en particular, su inc. $2^{\circ}$ ) de la Convención contra la Tortura y otros Tratos o Penas Grueles, Inhumanos o Degradantes, el Art. $23^{\circ}$ de la C.E.T.F.D.C.M. y el Arr. $41^{\circ}$ de la C.D.N.

Se trata -según Pinto- de un criterio hermenéutico informador del derecho de los derechos humanos, en cuyo mérito se debe acudir a la norma más amplia o a la interpretación más extensiva cuando se trata de reconocer derechos protegidos e, inversamente, a la norma o a la interpretación más restringidas cuando se trata de establecer restricciones permanentes al ejercicio de los derechos o de suspenderlos en forma extraordinaria ${ }^{17}$.

Dicha pauta axiológica ha sido entronizada en la doctrina interpretativa que, en el plano del sistema interamericano de protección de los derechos humanos, desarrolla la Corte Interamericana, órgano que ha indicado que si a una misma situación son aplicables la C.A.D.H. y otro tratado internacional, debe prevalecer la norma más favorable a la persona humana ${ }^{18}$. Recientemente, y en profundización de la aludida visión, ha sostenido - mutatis mutandi- que las garantías mínimas establecidas en un precepto de un Pacto internacional (en el caso, el de Derechos Civiles y Políticos) son susceptibles de expansión a la luz de otros instrumentos internacionales (en el particular, la Conven-

República Argentina, 2001, pp. 175-205; «La operatividad de los derechos y las garantías no obstante las omisiones o insuficiencias reglamentarias inconstitucionales», en el libro colectivo coordinado por Germán Bidart Campos y Andrés Gil Domínguez: Instituciones de la Ciudad Autónoma de Buenos Aires, Ed. La Ley, Buenos Aires, República Argentina, 2001, pp. 97-128; "Jurisdicción constitucional y control de constitucionalidad de los tratados y convenios internacionales", en la obra colectiva coordinada por Jorge A. Asbun, Academia Boliviana de Estudios Constitucionales, Santa Cruz de la Sierra, Bolivia, en prensa.

17 Mónica Pinto: «El principio pro homine. Criterios de hermenéutica y pautas para la regulación de los derechos humanos", en loc. cit. nota 14 [La aplicación de los tratados...], p. 163.

18 OC-5/85, del 13 de noviembre de 1985, que le fuera requerida por Costa Rica el 8 de julio del mismo año: "La colegiación obligatoria de periodistas -arts. $13^{\circ}$ y $29^{\circ}$ Convención Americana sobre Derechos Humanos-»; Serie "A», Fallos y Opiniones, $N^{\circ} 5$, Secretaría de la Corte, San José, Costa Rica, párrafo 52, p. 31. 
ción de Viena sobre Relaciones Consulares), que amplían el horizonte de protección de los justiciables ${ }^{19}$.

Para finalizar este señalamiento, cabe recordar a manera de ejemplo que algunas irradiaciones del mencionado Art. $29^{\circ}$ de la C.A.D.H. quedan plasmadas en ciertos patrones hermenéuticos por conducto de los cuales ninguna disposición de dicha Convención puede ser interpretada en el sentido de limitar el goce y el ejercicio de cualquier derecho o libertad que puedan estar reconocidos de acuerdo con las leyes de cualquiera de los Estados Partes o de conformidad con otra convención en que sea parte uno de dichos Estados (inc. 'b'); o no puede serlo en el sentido de excluir otros derechos y garantías que son inherentes al ser humano o que se derivan de la forma democrática representativa de gobierno (inc. 'c').

IV. Un análisis del problema a la luz de la doctrina de las omisiones inconstitucionales. Su posible corrección por vía jurisdiccional

\section{Sustento normativo y conductista de la supremacía constitucional}

Nuestra Corte Suprema sostuvo, en uno de los párrafos más célebres de su doctrina judicial, que las garantías individuales existen y protegen por el solo hecho de estar consagradas en la Constitución e independientemente de las leyes reglamentarias; las declaraciones, derechos y garantías no son simples fórmulas teóricas, porque cada uno de los artículos y cláusulas que las contienen poseen fuerza obligatoria para los individuos, para las autoridades y para toda la Nación ${ }^{20}$.

La contundencia léxica de aquel mensaje de la Corte no siempre ha recibido un acompañamiento análogamente firme en el sendero fácti-

19 OC-16/99, del 1 de octubre de 1999, solicitada por México el 9 de diciembre de 1997: «El derecho a la información sobre la asistencia consular en el marco de las garantías del debido proceso legal», ap. XIII Opinión, párrafo 141, pto. 6, p. 90.

20 In re: 'Siri' (fallos, 239:459). La alusión relativa a la fuerza obligatoria de los artículos y cláusulas constitucionales se debe a que en el mencionado caso la Corte citó expresamente a Joaquín V. González (Manual de la Constitución Argentina, Obras Completas, Vol. III, Nos. 82, 89 y 90, Bs. As., Rep. Arg., 1935), receptando tal aseveración e inoculándola al fallo. 
co. Desde hace bastante tiempo, tal realidad nos ha movido a estudiar la problemática de las omisiones inconstitucionales ${ }^{21}$, a comprometernos intelectualmente en la búsqueda de las herramientas procesales idóneas para superarlas, y promover, precisamente a través de la actuación judicial, que el órgano estatal remiso cumpla con los dictados de la Ley Fundamental y de los tratados internacionales sobre derechos humanos recipiendarios de idéntica jerarquía.

Es que, como subraya Sagüés, el principio de supremacía constitucional además de tener sustento normativo (cfr. Art. $31^{\circ}$ de la Ley Fundamental), requiere sustento conductista, es decir, el comportamiento de los operadores de la Constitución y su voluntad de cumplirla, como de castigar las infracciones a tal supremacía ${ }^{22}$.

\section{Las perspectivas normológica, sociológica y dikelógica}

Vinculado con lo anteriormente apuntado, nos preguntamos: ¿Es suficiente la mera "declamación" de derechos en los textos constitucionales? Absolutamente, no. La dimensión normológica debe complementarse con vigencia sociológica $-y$, ambas, con la perspectiva dikelógica (o axiológica)-, pues si la sociológica se desvanece, concluye por obturar el vigor normativo de la Constitución y su efectividad aplicativa, al tiempo de recrear inicuas frustraciones.

Parafraseando a Pérez Luño, una visión integral del problema residiría en la tentativa de captar al derecho en su entero desenvolvimiento tridimensional, desde su génesis en las conductas sociales hasta su formalización normativa y su legitimación axiológica, conjugando una perspectiva iusnaturalista con la teoría de la experiencia jurídica ${ }^{23}$. El

21 Ver, por ejemplo, de Víctor Bazán: “Un sendero que merece ser transitado: el control de la inconstitucionalidad omisivan, en el libro colectivo coordinado por el mismo autor: Desafíos del control de constitucionalidad, Ediciones Ciudad Argentina, Bs. As., Rep. Arg., 1996, pp. 171-269; "Hacia la plena exigibilidad de los preceptos constitucionales: el control de las omisiones inconstitucionales. Especial referencia a los casos de Brasil y Argentina", en el libro colectivo coordinado por el mismo autor: Inconstitucionalidad por omisión, Temis, Bogotá, Colombia, 1997, pp. 41-108; y más recientemente, "Omisiones inconstitucionales y justiciabilidad de los derechos", Revista Jurídica del Perú, Año LI, N²5, Trujillo, Perú, agosto de 2001, Sección Doctrina, pp. 1-20.

22 Néstor Pedro Sagüés, en el prólogo al libro de Alberto B. Bianchi: Control de constitucionalidad, Ed. Ábaco, Bs. As., Rep. Arg., 1992, pp. 13-14. 
citado autor español adscribe a la tesis del iusnaturalismo crítico y deontológico, que -según su explicación- no niega juridicidad al derecho positivo injusto, mas establece los criterios para comprobar su disvalor $y$, por lo tanto, para fundamentar su crítica y su sustitución por un orden jurídico justo. Subraya el catedrático aludido que la razón de ser del iusnaturalismo deontológico reside en ofrecer un concepto de juridicidad general y comprensivo no sólo del derecho existente sino de las pautas axiológicas que deben informar al derecho positivo y que, cuando no lo hacen, legitiman su denuncia. Añade que ambos planos no se confunden, pero tampoco pueden ser concebidos como compartimientos estancos separados por una fractura epistemológica insalvable, desgranando a partir de tal percepción la conjugación del iusnaturalismo con la teoría de la experiencia jurídica.

Mutatis mutandi, advierte Ferrajoli sobre la convergencia de dos principios que, con las pertinentes adaptaciones de acuerdo con los diversos derechos de que se trate, se encuentran dotados de un alcance garantista de carácter general. En primer término, el principio de legalidad: para que las prestaciones que satisfacen los derechos sociales sean impuestas como obligaciones a los poderes públicos y no abandonadas al arbitrio administrativo, considera necesario que legislativamente se prevean en forma unívoca sus presupuestos vinculantes y se identifiquen con claridad sus órganos y procedimientos ${ }^{24}$. Por su parte, el que entiende como segundo principio garantista de carácter general es el de jurisdiccionalidad. Al respecto, y en orden a que las lesiones de los

23 Antonio-Enrique Pérez Luño: «En torno a la fundamentación iusnaturalista de los derechos humanos", separata de la Revista de Ciencias Sociales, $N^{\circ} 41$, primer y segundo semestres de 1996, Facultad de Derecho y Ciencias Sociales, Universidad de Valparaíso, Chile, pp. 241-242.

24 Añade que para algunos derechos sociales, como el derecho a la subsistencia, la cuestión es relativamente simple, dado que basta la previsión legal de subsidios o salarios mínimos para todas las personas que no cuenten con los mínimos vitales y la atribución a éstas de un derecho de crédito correlativo. Considera que son menos simples, mas igualmente practicables, las garantías legales de los derechos a la educación y a la salud. Por el contrario, juzga que, para otros derechos -como el derecho al trabajo o a la vivienda, es mucho más difícil una legislación social, aunque sólo sea por el carácter irrealizable de su satisfacción igual, ni siquiera mínima (Ferrajoli,: Derecho y razón [Teoría del garantismo penal], $2^{a}$ ed., Ed. Trotta; trad. de Perfecto Andrés Ibáñez, Alfonzo Ruiz Miguel, Juan Carlos Bayón Mohino, Juan Terradillos Basoco, Rocío Cantareros Bandrés; Madrid, España, 1997, p. 917). 
derechos fundamentales sean sancionadas y eliminadas, estima necesario que éstos sean todos justiciables, es decir, accionables en juicio frente a los sujetos responsables de su violación, sea por comisión o por omisión. Apunta que semejante garantía, establecida en vía de principio por el Art. $24^{\circ}$ de la Constitución italiana, debería tener por campo privilegiado no el derecho penal, sino el derecho privado y el derecho administrativo y exigiría una reforma de los modelos tradicionales de legalidad civil y administrativa idónea para transformar en derechos perfectos aquellos que actualmente son sólo concesiones, expectativas, intereses legitimos [énfasis propio] ${ }^{25}$.

Con toda nitidez agrega el citado profesor italiano que, para transformar a estos últimos en derechos perfectos, sería necesario que las leyes $^{26}$ no sólo establecieran contenidos y presupuestos de cada derecho social, sino que identificasen también a los sujetos de derecho público investidos de las correlativas obligaciones funcionales, en cuyo contexto, toda omisión o violación de tales obligaciones, al comportar la lesión no ya de meros deberes o a la sumo de intereses legitimos sino directamente de derechos subjetivos, diera lugar a una acción judicial de posible ejercicio por el ciudadano perjudicado. Por último, y previo a postular la necesidad de ampliar la legitimación activa en materia de derechos sociales de naturaleza colectiva (involucrando a los nuevos sujetos colectivos, no necesariamente dotados de personalidad jurídica, que se hacen portadores de aquéllos), concluye que, junto a la participación política en las actividades de gobierno sobre las cuestiones reservadas a la mayoría, se desarrolle una no menos importante y generalizada participación judicial de los ciudadanos en la tutela y la satisfacción de sus derechos como instrumento tanto de autodefensa cuanto de control con relación a los poderes públicos ${ }^{27}$.

3. Desfase del Art. $259^{\circ}$ del C.C. frente al texto y al espíritu constitucionales postreforma de 1994

En el caso particular, el Art. $259^{\circ}$ del C.C. (texto según la Ley $\mathrm{N}^{\circ}$ 23.264 de 1985), en tanto no incluye a la madre del menor en su lista 
de legitimados activos para articular la acción de impugnación de la paternidad matrimonial, habría quedado desfasado vis-à-vis la nueva preceptiva constitucional diseñada por conducto de la reforma de 1994, que, por ejemplo, ha adjudicado jerarquía constitucional a un plexo de instrumentos internacionales sobre derechos humanos que dejan al desnudo la insuficiencia normativa del citado precepto del C.C. y, por ende, su incompatibilidad con el cuerpo y el alma de la Constitución.

Se estaría ante la presencia de un caso de inconstitucionalidad sobreviniente o, mutatis mutandi y en la terminología de Sagüés, de un supuesto de derogación por superación normativa ${ }^{28}$.

Específicamente en la hipótesis del Art. $259^{\circ}$ del C.C., nos parece que no operaría una derogación automática íntegra del mismo, sino en la medida (y en la porción) que aquél resulte contradictorio con la nueva preceptiva constitucional. Así lo ha resuelto la Corte Suprema, a manera de ejemplo, en Fallos, 213:185 y 461, 215:161, 217:456 y 223:156, puntualizando que las leyes anteriores a una reforma constitucional no son automáticamente derogadas por ésta, en tanto no sean contradictorias con sus disposiciones.

A nuestro entender, la estrechez normativa que en materia de legitimación activa ofrece la citada cláusula del C.C., no acordándosela a la progenitora para deducir la acción de impugnación de la paternidad matrimonial (omisión preceptiva solidificada por la visión hermenéutica conservadora de la decisión mayoritaria de la Corte), resulta inconstitucional, no sólo por colisionar con cláusulas expresas de ciertos tratados internacionales con alcurnia constitucional (v.gr., el Art. $16^{\circ}$, inc. $1^{\circ}$, ap. 'd', de la C.E.T.F.D.C.M. y los arts. $2^{\circ}$, inc. $1^{\circ} ; 3^{\circ}$, inc. $1^{\circ}$; $4^{\circ} ; 7^{\circ}$, inc. $1^{\circ} ; 8^{\circ} ; 12^{\circ}$ de la C.D.N.), sino por contradecir otros preceptos de la Carta Magna (por ejemplo, el Art. $75^{\circ}$, inc. 23). En tal contexto, violenta la garantía de igualdad de hombre y mujer (en el caso, en sus respectivos roles de marido y mujer o pretendido -aunque no realpadre y madre), deviene discriminatorio contra la mujer y desplaza hacia cuestiones tangenciales el verdadero centro de gravedad del problema: la imprescindible consideración del interés superior del niño y la necesidad de lograr la coincidencia -en la medida de lo posible- de la realidad jurídica con la realidad biológica en cuanto al emplazamiento del menor y de garantizar la búsqueda de su verdadera identidad.

28 Pedro Néstor Sagüés, Elementos de derecho constitucional, $T^{\circ} \mathrm{I}, 2^{\mathrm{a}}$ ed. actualiz. y ampl., Astrea, Bs. As., Rep. Arg., 1997, p. 83. 
En tal sentido, acordamos con las expresiones de Bidart Campos cuando afirma que la lectura de la decisión mayoritaria de la Corte convence una vez más acerca de que cuesta inocular en nuestros medios jurídicos -judiciales y no judiciales- la noción clave que supone que la legitimación procesal es un problema constitucional que la ley no puede resolver a su criterio, porque si no se asume la convicción de que el sistema de derechos y garantías de la Constitución se esteriliza cuando la legitimación no le facilita andamiento, se dilapidan todas las prédicas referidas a los derechos humanos ${ }^{29}$. Más adelante, el maestro concluye categóricamente aseverando que las leyes que niegan la legitimación para impedir que los jueces descubran la verdad material u objetiva, son inconstitucionales ${ }^{30}$ [en todos los casos, el énfasis corresponde al original].

En dirección afín, y para finalizar este subapartado, resta acotar que la Constitución, reforma de 1994 mediante, es ley superior y posterior al Art. $259^{\circ}$ del C.C., lo que claramente determina la prevalencia de aquélla sobre éste. Por lo demás, no es dable soslayar que el hecho de propiciar una visión amplia en materia de legitimación no conduce ineludiblemente al acogimiento de la sustancia del reclamo, es decir, no constituye garantía de éxito en la postulación, sino, y simplemente, garantía de acceso a la justicia. Luego, el juez interviniente meritará, sobre la base de las particularidades de la causa y la prueba rendida, la solución que -en definitiva- mejor se compadezca con el interés superior del menor.

Gutiérrez sintetiza su posición al respecto aseverando que se produce una incompatibilidad entre nuestra ley interna (Art. $259^{\circ}$ del C.C.) y los tratados internacionales ratificados por nuestro país, que han quedado equiparados al propio texto constitucional en cuanto a su jerarquía, por lo que -acota- si se presentara un conflicto en el que quedaran enfrentados dos valores jurídicamente protegidos como son el derecho a la identidad del niño y la protección de la paz familiar, cabe dar prevalencia a los derechos del niño y toda solución contraria sería inconstitucional, al igual que toda norma interna que discrimine a la mujer en sus derechos tiene que correr la misma suerte ${ }^{31}$. Añade

29 Germán J. Bidart Campos, op. cit. ["La legitimación de la madre..."], p. 22.

30 ldem.

31 Delia M. Gutiérrez, «Los tratados sobre derechos humanos y la acción de desconocimiento de la paternidad legítima", En: Derecho de familia - Revista interdisciplinaria de doctrina y jurisprudencia, Abeledo-Perrot, Bs. As., Rep. Arg., 1997, p. 77. 
que la igualdad entre ambos progenitores y la defensa del derecho a la identidad del niño permiten a la madre, por sí y en representación del hijo menor impúber ( $y$ al padre biológico - con alguna salvedad-) impugnar la paternidad del marido de la madre ${ }^{32}$.

\section{Acerca de las normas de prognosis}

La problemática analizada en torno de las omisiones inconstitucionales y los instrumentos procesales idóneos para lograr la corrección de las mismas, nos vincula (haciendo descender las cuestiones precedentemente señaladas a las concretas particularidades de la causa bajo comentario) con la temática de las normas de prognosis.

Las normas de prognosis ${ }^{33}$ son aquellas que, dictadas para operativizar un mandato constitucional concreto, han quedado desgastadas o desfasadas como consecuencia de circunstancias sobrevinientes, deviniendo -total o parcialmente- anacrónicas y, por ende, disvaliosas.

La moderna doctrina alemana destaca la posibilidad de controlar la omisión o inactividad del legislador en mejorar o corregir tales normas de prognosis. La omisión no se centra ya en la ausencia total o parcial de la norma, sino en la falta de adaptación o perfeccionamiento de la existente $^{34}$. Esta carencia o déficit de perfeccionamiento de las leyes asumirá particular importancia jurídico-constitucional cuando, de la falta de mejoras o correcciones resulten consecuencias gravosas para la efectivización de los derechos fundamentales ${ }^{35}$.

En opinión de dicha doctrina, se considera que generan obligación de desarrollo posterior -por parte del legislador- las situaciones en que se modifican las circunstancias determinantes (deber general de

$32 \mathrm{Id}$.

33 Rupert Stettner, "Die Verpflichtung des Gesetzgebers zu erneunten Tätigwerden bei fehlerhaften Prognosen, Deutsches Verwaltungsblatt (DVBl), c. 23, 1982, p. 1123 y ss.; citado por José Joaquim Gomes Canotilho, Direito Constitucional, $6^{\mathrm{a}}$. ed. revis., Almedina, Coimbra, Portugal, 1993, p. 1091, nota 49.

34 José Joaquim Gomes Canotilho, op. cit. [Direito ...], p. 1091.

35 Cfr. Peter Badura, «Die Verfassungsrechtliche Pflicht der gesetzgebenden Parlaments zur Nachbesserung von Gesetzen", en Staatsorganisation und Staatsfunktionen im Wandel, Festschrift für K. Eichenberger, p. 483 y Rupert Stettner, op. cit. [“Die Verpflichtung...", en $D V B \backslash$, p. 1123 ; cit. por José Joaquim Gomes Canotilho, op. cit. [Direito ...], idem.

36 José Julio Fernández Rodríguez, La inconstitucionalidad por omisión. Teoría general. Derecho Comparado. El caso español, Ed. Civitas, Madrid, España, 1998, p. 150. 
adecuación o allgemeiner Nachbessenrungsvorbehalt), los casos de necesaria corrección en los supuestos de prognosis errónea y la hipótesis de mejora a posteriori ${ }^{36}$.

Mutatis mutandi, nos preguntamos si el criterio sentado por la Corte en los casos "Bonorino Peró», "Perugini”, "Durañona y Vedia» y "Grieben" ${ }^{37}$ (en los que dicho tribunal estuvo integrado por conjueces), no recogerían -con grandes reflejos anticipatorios-, algunos aspectos del control sobre las normas de prognosis. Al respecto, recuérdese que en aquellos fallos -palabras más, palabras menos-, se dijo, en referencia a la obligación del entonces artículo constitucional 96 (hoy 110): «La obligación constitucional de mantener el significado económico de aquellas retribuciones [de los magistrados judiciales] debe llevarse a cabo cuando su desfase se produce "con una intensidad deteriorante»» - $\mathrm{el}$ remarcado nos corresponde- ${ }^{38}$.

Como quedara expuesto, la omisión del legislador en complementar el Art. $259^{\circ}$ del C.C., adecuándolo a los actuales lineamientos constitucionales y acordando legitimación a la madre, provoca que la citada norma del plexo normativo civil haya quedado desfasada como consecuencia de circunstancias sobrevinientes (la reforma constitucional), deviniendo parcialmente anacrónica y, por lo tanto, disvaliosa de cara a la exigencia de un tratamiento igualitario entre hombre y mujer y a la trascendente obligación de garantizar una consideración primordial en pro del interés superior del menor.

\section{El recurso a las sentencias aditivas}

Sentado lo precedente, resta analizar si existiría la posibilidad de corregir judicialmente la situación discriminatoria y anticonstitucional

37 De ese conjunto de fallos, el recaído en «Bonorino Peró» el 15 de noviembre de 1985 -Jurisprudencia Argentina, T 1986 -I, Bs. As., Rep. Arg., p. 95 y ss.- inauguró el camino seguido luego por los restantes y concretó un control de constitucionalidad con sentido institucional de una omisión inconstitucional: la de mantener «actualizada con significación económica la remuneración de los jueces, cuando un deterioro significativo trasuntaba en esa omisión una violación a la garantía de intangibilidad impuesta por el [ex] Art. $96^{\circ}$ [hoy $110^{\circ}$ ] de la Constitución", dando operatividad a la mencionada garantía (Germán J. Bidart Campos: La interpretación y el control constitucionales en la jurisdicción constitucional, Ediar, Bs. As., Rep. Arg., 1987, p. 100).

38 Ver v.gr., en «Durañona y Vedia»-considerando $6^{\circ}-$, Jurisprudencia Argentina, $\mathrm{T}^{\circ}$ 1986-IV, Bs. As., Rep. Arg., pp. 52-53. 
generada por la norma desfasada, pues -de lo contrario-nos limitaríamos a brindar una elucubración meramente teórica sin acompañamiento en el sendero fáctico ${ }^{39}$.

Respondemos afirmativamente al interrogante planteado. En efecto, estimamos que podría recurrirse al dictado de las denominadas sentencias aditivas, las que -originadas en el derecho europeo, mas adaptadas a las peculiaridades de nuestro sistema de control de constitucionalidad- supondrían la declaración de la inconstitucionalidad omisiva en el caso concreto y con efectos inter partes, darían solución puntual a una situación disvaliosa, mas dejarían latente y abierta la posibilidad de que en cualquier momento el órgano renuente emita la norma que resulta suplida o complementada por tal modalidad de sentencias ${ }^{40}$. De ese modo, se sortearía el reduccionismo que en materia de legitimación activa presenta el Art. $259^{\circ}$ del C.C., adecuándolo a las circunstancias y exigencias que la Constitución y los tratados internacionales sobre derechos humanos con idéntica jerarquía imponen en la hora actual.

Se ha afirmado que las sentencias aditivas incorporan un nuevo elemento a un enunciado legal, extienden el contenido normativo de un precepto a un supuesto fáctico no previsto, transformando un texto ilegítimo en legítimo mediante la adición de una nueva prescripción normativa ${ }^{41}$.

39 En otro lugar sostuvimos que deberian ponerse en funcionamiento medios idóneos para garantizar la efectividad del fallo que acoja la petición de declaración de inconstitucionalidad por omisión, en orden a que dicha sentencia no se torne ilusoria y, por ende, frustránea de la solución que dispensa; ello, para evitar caer en la inocuidad genérica del sistema portugués (Art. 283 ${ }^{\circ}$ ) o en la específica del brasileño (Art. 103, parágrafo $2^{\circ}$ ), cuando el órgano remiso es el Poder Legislativo (véase Víctor Bazán: "Inconstitucionalidad por omisión: la experiencia brasileña y un ejemplo a tener en cuenta por el derecho argentino", En : Entre Abogados, Año IV, $N^{\circ} 8$, Foro de Abogados, San Juan, Rep. Arg., 1996, pp. 18-30, en esp., pp. 24 y 26-28).

40 En ese sentido, es dable recordar -a manera de ejemplo- que ha existido algún movimiento legislativo para modificar el Art. $259^{\circ}$ del C.C.; por ejemplo, incluyendo en la lista de legitimados activos a la madre (ver Diario del Senado de la Nación, Año XIV, No 105, 30/10/98; http:/www.salvador.edu.ar/ua 1-4b10.htm). También, en la Cámara de Diputados; v.gr., Expediente 1.678-D-01, de autoría de Barbagelata y otros (Boletin de Asuntos Entrados, N 6, TP N²8, Período 2001, Cámara de Diputados de la Nación; http://www1.hodn.gov.ar/dependencias/dsecretaria/bae2001/bae01_dip06tp28.htm).

41 María de los Ángeles Gutiérrez Zarza, "Las sentencias interpretativas y aditivas del Tribunal Constitucional español», Revista de Derecho Procesal, N³, 1995, p. 1007. 
El presupuesto del pronunciamiento con efectos aditivos radica en la omisión del legislador. En tal sentido, se ha enseñado que la sentencia aditiva no se agota en una operación hermenéutica permitida, sino que, sobre la base de la constatación de una (inconstitucional) omisión normativa en la disposición impugnada, la decisión hace aparecer una norma en aquel vacío de formulación ${ }^{42}$.

En otras palabras, y como recuerda Vecina Cifuentes, el precepto legal presenta un contenido normativo menor al que constitucionalmente debería tener ${ }^{43}$, oponiéndose a la Constitución no por lo que dice sino por lo que no dice, razón por la cual este tipo de sentencias resultan de utilidad para remediar las lesiones al principio de igualdad que ocasionan las omisiones del legislador ${ }^{44}$.

Las «sentencias aditivas» reciben diversas denominaciones y son visualizadas con distintas variantes por parte de los Tribunales Constitucionales italiano, español y alemán.

Así, la Corte Constitucional de Italia (país en el que -según se ha sostenido- tuvo origen esta tipología de pronunciamientos) acude al dictado de sentencias "aditivas de principio», que entrañan un instrumento para declarar la inconstitucionalidad de una ley, junto a las sentencias "derogatorias", sólo que mientras en éstas se elimina del ordenamiento jurídico una manifestación de voluntad positiva del legislador, con aquéllas la mentada eliminación se posa sobre una manifestación de voluntad negativa de éste, produciendo -como efecto inmediato- una nueva norma positiva en el plexo jurídico. A modo de digresión, estimulada por el valor cuantitativo y cualitativo de la praxis italiana, y sobre la base de lo informado por Casavola, diremos que la aludida Corte ha recurrido

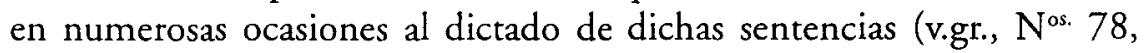
109 y 243 -todas de 1993-), que se expresan -ya desde el punto de vista terminológico- con una fórmula que indica que se "declara la inconstitucionalidad del Art. ... en la parte en que no prevé (no contiene; no comprende; o excluye)...." ${ }^{45}$.

42 Giustino D'Orazio, "Aspectos y problemas de la justicia constitucional italiana", en R.V.A.P., $\mathrm{N}^{\circ} 31,1991$, p. 59 y ss.; aludido por María de los Ángeles Gutiérrez Zarza, , op. cit., p. 1008.

43 Javier Vecina Cifuentes, "Las sentencias "aditivas" del Tribunal Constitucional y el respeto al legisladorm, Revista Justicia, Nos. III-IV, 1993, p. 477 y ss.

44 María de los Ángeles Gutiérrez Zarza, op. cit., p. 1008.

45 «La labor del Tribunal Constitucional italiano durante el año 1993 (texto presen- 
Por su parte, el Tribunal Constitucional español ha plasmado ese tipo de pronunciamientos, v.gr., en las S.T.C. 11/1981, 103/1983, $104 / 1983,142 / 1990,222 / 1992$ y $3 / 1993^{46}$. En torno del tema se ha sostenido que dichas sentencias suelen estar conectadas con la inconstitucionalidad por omisión, al ser causadas por el incorrecto desarrollo legislativo del asunto que se sustancia ante el aludido Tribunal y que, precisamente, es tal omisión la que posibilita y justifica el añadido de los elementos que conformarán la nueva norma, con la que se trata de superar la situación contraria a la Constitución que venía determinada por esa omisión $n^{47}$.

Por último, y previo a dar paso al epílogo del presente trabajo, permítasenos recordar que el Tribunal Constitucional Federal alemán distingue entre "omisiones todavía constitucionales" $\mathrm{y}$ «omisiones inconstitucionales», mediante las sentencias «apelativas», "que son el resultado de la constatación de situaciones todavía constitucionales, donde, simultáneamente, se hace una apelación al legislador para alterar la situación, eventualmente dentro de un plazo expresamente determinado por el Tribunal, con la consecuencia adicional, caso de que ello fuera posible, de aplicar directamente el mandato constitucional ${ }^{48}$.

\section{Consideraciones finales}

El trabajo que ponemos a consideración del lector, ingresa en su último tramo. Previo a dar paso a algunas ideas finales, deseábamos

tado en rueda de prensa por el Presidente Casavola)", en la sección "Crónicas y Documentación» de Cuadernos de la Cátedra Fadrique Furió Ceriol, N7, trad. de Remedio Sánchez Férriz y Luis Jimena Quesada, Universidad de Valencia, España, 1994, p. 149.

46 José Julio Fernández Rodríguez, op. cit., p. 235.

Figueruelo Burrieza, por su parte, incluye en la reseña a las sentencias 81/1982 y 15/1982 (Ángela Figueruelo Burrieza: "La incidencia positiva del Tribunal Constitucional en el Poder Legislativo", Revista de Estudios Políticos, No 81, junio-septiembre de 1993, Madrid, España, p. 70).

47 José Julio Fernández Rodríguez, fdem.

48 Francisco Fernández Segado, «Los nuevos retos del Estado social para la protección jurisdiccional de los derechos fundamentales" (Conclusión), El Derecho, 25/07/94, Bs. As., Rep. Arg., p. 4, nota 113. Para formular tal apreciación, el catedrático español se apoya en Wolfgang Zeidler, "A Justiça Constitucional no quadro das funçôes do Estado. Em especial tipos, conteuido e efeitos das decisôes sobre a constitucionalidade de normas jurídicas, en Boletim de Documentação e Direito Comparado do Ministério de Justiça de Portugal, Nos. 29-30, Lisboa, Portugal, pp. 61 y 64-69. 
advertir que en modo alguno nos propusimos aportar verdades inconcusas sino -y solamente-ciertas reflexiones preliminares en torno de una problemática conflictiva que presenta variadas aristas axiológicamente relevantes y dignas de continuos y renovados debates. Veamos:

1. Uno de los importantes avances que ha experimentado la Constitución al influjo de la reforma de 1994 (al menos desde el ámbito normológico), enraíza en el diseño de un nuevo paradigma del principio de igualdad, caracterizado por la exigencia de complementación de la igualdad formal (Art. $16^{\circ}$ ) con la igualdad material o juridica, lo que queda corporizado en el texto constitucional con una nueva fórmula léxica que, con matices, puede resumirse como: igualdad real de oportunidades, posibilidades y de trato (ver, v.gr., arts. $37^{\circ} ; 75^{\circ}$, incs. $2,19^{\circ} \mathrm{y}$ $23^{\circ}$ ), para cuya no eufemística operativización se requiere del Estado que actúe equiparando situaciones de irrazonable desigualdad, paliando arbitrarias discriminaciones, previniendo o corrigiendo infundadas disparidades ${ }^{49}$.

En tren de satisfacer tan trascendente objetivo, y en el contexto genérico de las medidas de acción positiva previstas, por ejemplo, en el Art. $75^{\circ}$, inc. 23 , quedan decididamente vinculadas las sentencias judiciales como garantía de observancia de la Constitución y significativo reaseguro en punto a que las obligaciones asumidas por el Estado al ratificar internacionalmente los tratados sobre derechos humanos no queden incumplidas, por acción u omisión, ya que mientras el tratado esté vigente debe ser observado por las partes (Art. $26^{\circ}$ de la Convención de Viena de 1969 sobre el Derecho de los Tratados); y tal cumplimiento, concretarse de buena fe (señalado Art. $26^{\circ}$, parte in fine, y Art. $31^{\circ}$, inc. $1^{\circ}$, ibid.), siendo improcedente alegar o invocar disposiciones del derecho interno para au toexonerarse o intentar justificar la exención de cumplimiento de las obligaciones emergentes del aludido acto jurídico internacional, salvo cuando el vicio de consentimiento del Estado en obligarse por el tratado, concerniente a la competencia para celebrarlo, sea manifiesta ${ }^{50}$ y afecte a una norma de im-

49 Ver Víctor Bazán, "La Constitución y la ju risprudencia contra la inercia legislativa o el principio del fin de las excusas", en el libro coordinado por Germán Bidart Campos, "Economía, Constitución y derechos sociales», Ediar, Bs. As., 1997, pp. 111-174, en esp. pp. 124-130.

50 Según el Art. 46.2 de la Convención de Viena de 1969 sobre el Derecho de los 
portancia fundamental de su derecho interno (Art. $27^{\circ}$ en conjunción con el Art. $46^{\circ}$, ibid.), caso este último en el que -de acuerdo con De la Guardia- el tratado sería nulo de nulidad relativa por el vicio formal de defecto de competencia ${ }^{51}$.

Como con acierto afirma Bidart Campos, desde el derecho internacional de los derechos humanos se coadyuva a tonificar la fuerza normativa de la Constitución con y por obra de una fuente heterónoma que auspicia, con carácter mínimo y subsidiario, conferir completitud al sistema interno de derechos y poner en movimiento una retroalimentación constante entre él y el derecho internaciona ${ }^{52}$; añadiendo que un derecho internacional imbuido de personalismo humanista ostenta finalidad equivalente a la del constitucionalismo democrático, tanto en lo atinente al sistema de derechos cuanto en lo vinculado a la organización del poder estatal ${ }^{53}$ [énfasis del original].

2. No compartimos la visión reduccionista que en materia de legitimación activa de la madre para articular la acción de impugnación de la paternidad del marido evidencia la Corte, y que dejara plasmada en el voto mayoritario emitido en la causa «D. de P. V., A. v. O., C. H.»"

Tratados, una violación es «manifiesta» si resulta objetivamente evidente para cualquier Estado que proceda en la materia conforme a la práctica usual y de buena fe.

51 Ernesto De la Guardia, Derecho de los tratados internacionales, Ábaco, Bs. As., Rep. Arg., 1997, pp. 272 y 271.

52 Germán J. Bidart Campos, El Derecho de la Constitución y su fuerza normativa, Ediar, Bs. As., Rep. Arg., 1995, p. 468.

53 Ibidem, p. 469.

$54 \mathrm{Y}$ que contrasta con el laudable criterio sustentado por el mismo Tribunal in re «M. 354. XXXIV. Recurso de hecho. "M., S. M. c/ M., M. A. y otros"", pronunciamiento por el cual hizo lugar a la queja, declaró procedente el recurso extraordinario y dejó sin efecto la sentencia apelada que había rechazado in limine la demanda de impugnación de paternidad y de reclamación de filiación interpuesta por el Asesor de Menores en representación de un incapaz.

Para así decidir, la Corte sostuvo que el pronunciamiento cuestionado era arbitrario dado que, en el caso, tanto el marido de la madre de la menor como el supuesto padre, con la conformidad de la progenitora, habían requerido que el Ministerio Público de Menores e Incapaces promueva la acción, habiendo el a quo prescindido del alcance de las facultades que le competen al citado Ministerio tras la sanción de la Ley N ${ }^{\circ} 24.946$ (B.O. del 23/03/98 y fe de erratas del 30/03/98), particularmente la posibilidad de promover acciones en forma directa (Art. $25^{\circ}$, inc. ' $i$; 54 , inc. 'c' y 55 , inc. 'b') y de la articulación de estas funciones con los principios consagrados por la Convención sobre los Derechos del Niño.

Asimismo, el Tribunal expresó -en valiosa apreciación-que las cuestiones atinentes a la legitimación están inescindiblemente unidas al derecho sustancial que se debatía en la 
Cualesquiera sea el camino que se discurra para examinar la cuestión que fuera sometida a la consideración del Alto Tribunal (examinando con detenimiento los postulados de la C.E.T.F.D.C.M. -al modo como lo efectúan Petracchi y Bossert- o haciéndolo en los de la C.D.N. -como lo concreta Vázquez-) el punto de confluencia al que se arriba, y que traduce el valor más trascendente que subyace en la intersección de la normativa pertinente de la primera de las Convenciones nombradas (v.gr., el Art. $16^{\circ}$, inc. $1^{\circ}$, ap. 'd') y la de la C.D.N. (por ejemplo, los arts. $2^{\circ}$, inc. $1^{\circ}$; $3^{\circ}$, inc. $1^{\circ} ; 4^{\circ} ; 7^{\circ}$, inc. $1^{\circ} ; 8^{\circ} ; 12^{\circ}$ ), estriba en la obligación estatal de considerar primordialmente el interés superior del menor.

La posición mayoritaria del Tribunal conduce a una situación disvaliosa al abroquelarse detrás de una visión reduccionista en materia de legitimación procesal que, en definitiva, se erige en una rémora para el pleno despliegue del derecho constitucional a la identidad y a obtener judicialmente la coincidencia de la filiación legal con la biológica -en la medida en que ello resulte más beneficioso para el menor-.

Paralelamente, posa su mirada sobre un cúmulo de cuestiones tangenciales (el mantenimiento del sosiego y la certeza en los vínculos familiares; la política legislativa; el margen de apreciación del Estado; la distinción legítima por imperativos del bien común, -inter alia-),

causa, aun cuando la filiación de un menor, por ser materia de derecho común, no suscite -como regla- la apertura del recurso extraordinario.

55 Para un análisis de las soluciones que ofrece el derecho comparado respecto de la inconstitucionalidad por omisión, sea desde los textos constitucionales o desde la doctrina judicial, ver Víctor Bazán, op. cit. [«Un sendero que merece...”, en Desafios del...], pp. 175-201.

Sólo permítasenos señalar que, además de los conocidos casos de -inter alia- la ex Yugoslavia, Portugal, Alemania, España, Brasil y, ya en el contexto argentino, de la Constitución de la Provincia de Río Negro, puede computarse-ejemplificativamenteun interesante precedente jurisdiccional en República Dominicana (del 24 de febrero de 1999) por el cual la Suprema Corte de Justicia declaró que el recurso de amparo previsto en el Art. $25^{\circ}$, inc. $1^{\circ}$, de la C.A.D.H. «es una institución del derecho positivo dominicano", por haber sido aquella Convención adoptada y aprobada por el Congreso el 25 de diciembre de 1977, en los términos del Art. $3^{\circ}$ de la Constitución de ese país; además, y ante la ausencia de norma procedimental relativa a dicho "recurso", se entregó a delinear los trazos al que debe sujetarse el procedimiento en el que discurra el amparo (competencia, plazo para interponerlo, audiencia para su conocimiento, parámetro temporal al que debe ajustarse el juez al dictar sentencia, costas, etcétera) -ver, respectivamente, puntos dispositivos primero y segundo de la aludida resolución-. 
soslayando la pauta axiológica imperativamente aplicable consistente en la consideración primordial del interés superior del niño.

Por su parte, es obvio que los magistrados jurisdiccionales deben asumir el compromiso y cumplir la obligación contenida en el Art. $75^{\circ}$, inc. 23, de la Constitución Nacional, concebida como un plus protectivo que, desde la norma y el espíritu constitucionales, se alza contra toda discriminación irrazonable y arbitraria, como la que -de acuerdo con todo lo aquí analizado- depara el texto del Art. $259^{\circ}$ del C.C. al negar legitimación activa a la madre para deducir la acción de impugnación de la paternidad del marido, pues -a no dudarlo- la legitimación se encuentra inextricablemente unida al derecho sustancial que se debate en la causa que involucra valores trascendentes que tienen al menor como protagonista (sujeto y no objeto de derechos).

3. Desde otro perfil, cabe recordar que el control sobre las omisiones inconstitucionales no apunta a habilitar un "arma» para convalidar "indebidas interferencias» de la judicatura en los restantes órganos estaduales $^{55}$. De lo que sí se trata es de evitar que la mora legislativa (o la de los órganos competentes) bloquee la fuerza normativa de la Constitución. Un argumento de no menor centralidad indica que la Ley Fundamental es la fuente primera y superior (es «fuente de fuentes»), no así los órganos del poder constituido, los que (improcedentemente) se autoarrogarían la calidad de fuentes de legitimidad (inclusive sobre la propia Constitución) en la medida que, al influjo de su inercia, harían sucumbir los designios constitucionales. Sentado ello, es casi de perogrullo reiterar la exigencia de una elevada dosis de prudencia en el accionar de la magistratura jurisdiccional, para sortear el riesgo de deslizarse hacia una "banalización de las inconstitucionalidades" ${ }^{56}$.

Como señala Mortati, con ello no se opera un intercambio de funciones entre el poder legislativo y el judicial, dado que éste no se extralimita de su propia competencia ni sustituye al legislador si hace aplicación del derecho vigente a los casos concretos siguiendo el orden jerárquico de las fuentes, dando así preferencia a la Constitución respecto de la ley, siempre que la primera -interpretada armónicamente con todo el sistema normativo- sea idónea para orientar la decisión ${ }^{57}$.

56 La expresión corresponde a José Joaquim Gomes Canotilho, Constituição dirigente e vinculação do legislador. Contributo para a compreensão das normas constitucionais programáticas, Coimbra Editora, Coimbra, Portugal, 1982, p. 333. 
Sea como fuere, siempre existirán antídotos o remedios contra los potenciales "desbordes» jurisdiccionales, v.gr.: la autolimitación judicial (self-restraint), la posibilidad de que el órgano remiso dicte en cualquier momento la norma que resulta suplida por la sentencia «aditiva» ${ }^{58}$, el sometimiento a juicio político o a jurado de enjuiciamiento a los jueces que cometieren graves faltas, incurrieren en reiteradas extralimitaciones, etc.

Creemos que debería despejarse el temor por la falacia de la «dictadura o gobierno de los jueces", pues casualmente en nuestro esquema institucional argentino a todos ellos viene dispensada la ardua tarea de controlar la incolumidad de la supremacía de la Constitución (y, por añadidura, de los tratados internacionales sobre derechos humanos que comparten su jerarquía), que puede resultar quebrada por acción u omisión. Además, y como puntualiza Zagrebelsky, justo es recordar que los jueces son, precisamente, los garantes de la complejidad estructural del-derecho en el Estado constitucional, es decir, de la necesaria y dúctil coexistencia entre ley, derechos y justicia ${ }^{59}$.

4. El multicitado Art. $259^{\circ}$ del C.C. adolece de inconstitucionalidad sobreviniente, en tanto no incluye a la madre del menor en la nómina de legitimados activos para articular la acción de impugnación de la paternidad matrimonial, y habría quedado desfasado vis-à-vis la nueva preceptiva constitucional diseñada por conducto de la reforma de 1994, que, por ejemplo, ha adjudicado jerarquía constitucional a un plexo de instrumentos internacionales sobre derechos humanos que desnudan la insuficiencia normativa del citado precepto del C.C. y, por ende, su incompatibilidad con la Ley Fundamental.

A nuestro entender, la estrechez normativa que en materia de legitimación activa ofrece el Art. $259^{\circ}$ del C.C., no acordando a la progenitora legitimación para deducir la acción de impugnación de la

57 Costantino Mortati, "Appunti per uno studio sui rimedi giurisdizionali contro comportamenti omissivi del legislatore", Problemi di Diritto Pubblico nell'attuale esperienza costituzionale reppublicana. Raccolta di scritti, Vol. III, Giuffrè, Milán, Italia, 1972, pp. $992-$ 993.

58 Refiriéndose a las sentencias "aditivas" y a las probables limitaciones para evitar los "excesos» judiciales, ver Alessandro Pizzorusso, Lecciones de Derecho Constitucional, $\mathrm{T}^{\circ} \mathrm{II}$, trad. de Javier Jiménez Campo, Centro de Estudios Constitucionales, Madrid, España, 1984, p. 342.

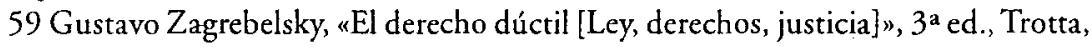
trad. de Marina Gascón, Madrid, 1999, p. 153. 
paternidad matrimonial (omisión preceptiva robustecida por la visión hermenéutica conservadora de la decisión mayoritaria de la Corte en la causa comentada), resulta inconstitucional, no sólo por colisionar con cláusulas expresas de ciertos tratados internacionales con alcurnia constitucional (v.gr., el Art. $16^{\circ}$, inc. $1^{\circ}$, ap. 'd', de la C.E.T.F.D.C.M. y los arts. $2^{\circ}$, inc. $1^{\circ} ; 3^{\circ}$, inc. $1^{\circ} ; 4^{\circ} ; 7^{\circ}$, inc. $1^{\circ} ; 8^{\circ} ; 12^{\circ}$ de la C.D.N.), sino por contradecir otros preceptos de la Carta Magna (por ejemplo, el Art. $75^{\circ}$, inc. 23). En tal sentido, violenta la garantía de igualdad de hombre y mujer (en el caso, en sus respectivos roles de marido y mujer o -supuesto- padre y madre), deviene discriminatorio contra la mujer y desplaza hacia coordenadas tangenciales el verdadero centro de gravedad del problema: la imprescindible consideración del interés superior del niño y la necesidad de lograr la coincidencia -en la medida de lo posible- de la realidad jurídica con la realidad biológica en cuanto al emplazamiento del menor y de garantizar la búsqueda de su verdadera identidad.

Las normas de prognosis son aquellas que, dictadas para operativizar un mandato constitucional concreto, han quedado desgastadas o desfasadas como consecuencia de circunstancias sobrevinientes, deviniendo -total o parcialmente- anacrónicas y, por ende, disvaliosas. Se configura la inconstitucionalidad, precisamente, por la falta en que el legislador incurre al omitir mejorarlas o corregirlas y en tanto de ello se desprendan consecuencias gravosas para la efectivización de derechos fundamentales.

Para salvar la omisión inconstitucional patentizada y el desfase de la norma cuestionada, estimamos que podría recurrirse al dictado de las denominadas sentencias aditivas, las que -originadas en el derecho europeo, mas adaptadas a las peculiaridades de nuestro sistema de control de constitucionalidad- supondrían la declaración de la inconstitucionalidad omisiva en el caso concreto y con efectos inter partes, darían solución puntual a una situación disvaliosa, mas dejarían latente y abierta la posibilidad de que en cualquier momento el órgano renuente emita la norma que resulta suplida o complementada por tal modalidad de sentencias. De ese modo, se sortearía el reduccionismo que en materia de legitimación activa presenta el Art. $259^{\circ}$ del C.C., adecuándolo a las circunstancias y exigencias que la Constitución y los tratados internacionales sobre derechos humanos con idéntica jerarquía imponen en la hora actual. 
Es que, como se ha enseñado, el problema de las omisiones del legislador cobra interés en cuanto a su control y posibilidades de corrección, no bajo el aspecto de perfección técnica en el desarrollo por el legislador de los principios y normas constitucionales o del grado de celeridad con que ponga en marcha institutos u órganos previstos por el constituyente, sino en la medida en que la inactividad del legislador provoque la lesión de derechos o libertades reconocidos en la Constitución o impida su pleno ejercicio $^{60}$.

5. Se impone la necesidad de un reajuste interpretativo de los preceptos infraconstitucionales a la luz de los nuevos parámetros contenidos en la Constitución y los tratados internacionales sobre derechos humanos con o sin jerarquía constitucional que, en cualquier caso, siempre ostentarán valencia supralegal.

Es que, como recuerda Perlingeri, corresponde redefinir el fundamento y la extensión de los institutos jurídicos y, especialmente, de aquellos civilísticos subrayando su perfil funcional en un intento de revitalización de las normas singulares a la luz de un renovado juicio de mérito ${ }^{61}$.

6. Para desterrar toda perspectiva prejuiciosa en materia de legitimación procesal en un supuesto como el discurrido en el proceso que motivara el fallo de la Corte reseñado en el presente trabajo, será importante tomar en consideración que de lo que se trata, simplemente, es de garantizar el acceso a la jurisdicción y no el éxito de la postulación, la que será analizada por el juez interviniente sobre la base de las particularidades de la causa y la prueba rendida, y dirimida del modo que mejor se compadezca con el interés superior del menor.

60 María Ángeles Ahumada Ruiz, «El control de constitucionalidad de las omisiones legislativas", En: Revista del Centro de Estudios Constitucionales, $\mathrm{N}^{\circ} 8$, enero/abril 1991, Madrid, España, p. 173.

61 Pietro Perlingieri, Il diritto civile nella legalità costituzionale, Napoli, 1991, $\mathrm{N}^{\circ} 141$, p. 200; citado por Julio César Rivera: «El Derecho Privado Constitucional», en: Revista de Derecho Privado y Comunitario $N^{\circ} 7$ [ "Derecho Privado en la reforma constitucional»], Rubinzal-Culzoni, Santa Fe, Rep. Arg., 1994, p. 51, nota a pie de página 62. 